\title{
Effect of dietary zinc on the growth and metabolic enzyme activities of golden mahseer (Tor putitora) fry
}

\author{
Kaustubh Bhagawati ${ }^{*}$, N. K. Chadha ${ }^{1}$, Debajit Sarma ${ }^{3}$, M. S. Akhtar ${ }^{3}$, Paramita B. \\ Sawant $^{1}$ and Simanku Borah ${ }^{2}$
}

${ }^{1}$ Division of Aquaculture, Central Institute of Fisheries Education (ICAR), Versova, Mumbai - 400061 (Maharastra), INDIA

${ }^{2}$ Division of Fisheries Resource Management, Central Institute of Fisheries Education (ICAR), Versova, Mumbai 400061 (Maharastra), INDIA

${ }^{3}$ Environmental Fish Biology and Nutrient Profiling Laboratory, ICAR-Directorate of Coldwater Fisheries Research Bhimtal, Nainital- 263136 (Uttarakhand), INDIA

*Corresponding author. E-mail: kaustabh.bhagawati@gmail.com

Received: October 20, 2015; Revised received: July 11, 2016; Accepted: August 08, 2016

\begin{abstract}
The golden mahseer (Tor putitora) is an important and high valued sport and food fish of national and international importance. Therefore for promotion of golden mahseer, proper mineral supplementation in early developmental stages is very important. The present study evaluated the effects of dietary zinc on growth, survival and physiological response of Tor putitora fry. One thousand eight hundred fry (avg.wt $54.35 \pm 3.09 \mathrm{mg}$ ) were randomly distributed into 6 treatment groups with triplicates each. Six iso-nitrogenous $(40 \pm 0.02 \%$ to $41.44 \pm 0.01 \%$ crude protein) semi-purified diets were prepared with graded levels of dietary zinc. Zinc sulphate was added as the dietary zinc source to the basal diet. The results indicated that specific growth rate (SGR) was of value $2.52 \pm 0.23$ gm of $T$. putitora fry which increased with dietary zinc levels up to a concentration of $40 \mathrm{mg} \mathrm{Zn} \mathrm{Kg}^{-1}$ in diet. The zinc dependent metabolic enzymes and antioxidant enzymes was also observed to be highest in groups supplemented with $40 \mathrm{mg} z i n c / \mathrm{kg}$ feed. The overall results of the present study suggest the efficacy of dietary zinc on growth, survival and physiological response of golden mahseer fry in order to garner the possibility of establishing the species to commercial aquaculture.
\end{abstract}

Keywords: Isonitrogenous, Metabolic enzymes, Specific growth rate, Tor putitora

\section{INTRODUCTION}

Tor putitora (golden mahseer) is a well-acknowledged, highly valued coldwater fish of India. Golden mahseer as a sport fish provides unparallel recreation to anglers from all over the world. As a food fish, it is highly esteemed and fetches the highest market price in north and north east of India. Despite its earlier abundance, T. putitora population has been declining in number and size in natural waters because of degradation of the aquatic environment and biological changes in the ecosystem. Therefore, the present concern is to conserve this species through artificial breeding, seed rearing and ranching into its natural habitats. But, the major bottleneck in successful seed propagation of this species is unavailability of suitable diet for larval rearing (Akhtar et al., 2013). Hence, a better understanding is required to study the nutritional role of trace minerals such as zinc where major research focus in needed, which will be essential for preparation of suitable larval diets. To address the research problem a necessary understanding is required to formulate an artificial diet en- riched with dietary zinc to know about the nutritional role of zinc in fish. Zinc is known to be an essential trace element for normal physiology, growth and development in terrestrial animals and fish (Liang et al., 2012). It serves as an integral part of nucleoproteins and regulates many metabolic processes of carbohydrate, lipid and protein metabolism (Lall, 2002). Zinc serves as a cofactor of many enzymes including carbonic anhydrase and is required for the activity of the antioxidant enzyme superoxide dismutase (Yousef et al., 2002). Zinc deficiency has been shown to produce impaired growth, increased mortality, eye cataract and poor feed utilization (Hasnat et al., 2012). Freshwater fish take up zinc from both water and food. However dietary zinc is more efficiently utilized to satisfy the nutritional requirement for the growing fish. Therefore in the present experiment, an attempt has been made to determine the optimum dietary zinc concentration on growth and physiological indices of the early developmental stages of golden mahseer (T. putitora) fry. 


\section{MATERIALS AND METHODS}

Experimental procedure: Fry of $T$. putitora $(54.85 \pm 3.09 \mathrm{mg}$, average weight $\pm \mathrm{SE})$ were procured from mahseer hatchery of Directorate of Coldwater Fisheries Research (DCFR), Bhimtal, Uttarakhand, India, and were acclimatized for ten days in rectangular FRP tanks. The fish were fed with macerated goat liver and control diet during acclimatization period. Before start of the experiment, the tanks were cleaned and disinfected using potassium permanganate $\left(\mathrm{KMnO}_{4}\right)$ solution of $5 \mathrm{ppm}$ concentration. All the experimental tanks were filled with water and kept for two days for conditioning before stocking the fishes. After 10 days of acclimation, fish were randomly distributed into six treatment groups in triplicates consisting of 18 uniform size (500 L capacity) plastic tanks (100 fish / tank). Each diet was assigned to triplicate tanks. The feeding trial lasted for 8 weeks. Feeding was done at ad-libitum twice in a day at 09:00 hours and at 17:00 hours so as to feed the fish near satiation. The fish were weighed every 2 weeks during the trial period. The water quality parameters were analyzed fortnightly and maintained at an optimum level for the proper growth and survival of the fishes. Water quality parameters were as follows: temperature, 18.45-24.35 ${ }^{0} \mathrm{C}$; dissolved oxygen, 7.15-8.76 mg L ${ }^{-1}$; $\mathrm{pH}$, 7-9; total

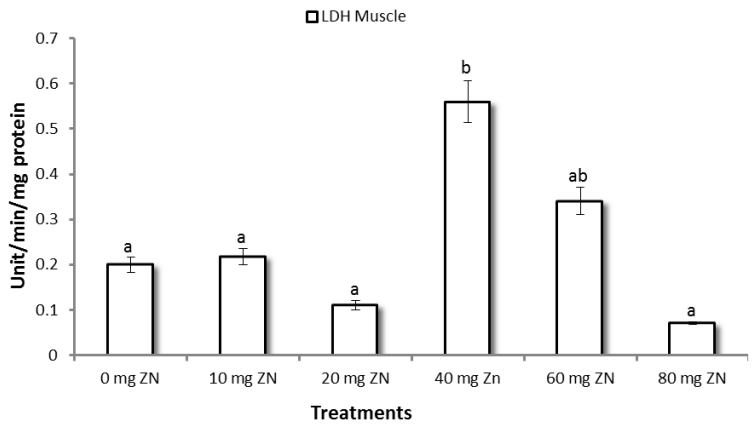

Fig.1. Effect of dietary zinc on LDH (Lactate dehydrogenase) activity in muscle of $T$. putitora reared for a period of 8 weeks (60 days). Values in the same series with different superscript ( $a$ and $b$ ) signify statistical differences ( $p$ <0.05), Data expressed as mean \pm S.E, $n=6$ (each replicate containing pooled samples of $15 \mathrm{fish}$ ).

alkalinity, $116.20-144.40 \mathrm{mg} \mathrm{L}^{-1}$; total hardness, 129.5 -155.5 $\mathrm{mgL}^{-1}$; total ammonia-nitrogen, 0.006-0.01 $\mathrm{mgL}^{-1}$. Zinc concentration of the rearing water was $0.01-0.03 \mathrm{mgL}^{-1}$ during the trial period.

Experimental diet and diet preparation: Six isonitrogenous $(40.00 \pm 0.02 \%$ to $41.44 \pm 0.01 \%$ crude protein) semi-purified experimental diets were formulated to contain graded levels of zinc by supplementing the basal diet with $0,10,20,40,60$ and $80 \mathrm{mg} \mathrm{kg}^{-1} \mathrm{Zn}$

Table 1. Diet composition and proximate analysis of the experimental diets (\% dry matter (DM) basis) fed to T. putitora fry during the experimental period.

\begin{tabular}{|c|c|c|c|c|c|c|}
\hline \multirow[b]{2}{*}{ Ingredients } & \multicolumn{6}{|c|}{ Diets } \\
\hline & $\mathbf{1}(0 \mathrm{mg} \mathrm{ZN})$ & $\mathbf{2}(10 \mathrm{mg} \mathrm{ZN})$ & $3(20 \mathrm{mg} \mathrm{ZN})$ & $4(40 \mathrm{mg} Z \mathrm{ZN})$ & $\begin{array}{c}5(60 \mathrm{mg} \\
\mathrm{ZN})\end{array}$ & $\begin{array}{c}6(80 \mathrm{mg} \\
\mathrm{ZN})\end{array}$ \\
\hline Casein (vitamin free) ${ }^{\mathrm{a}}$ & 24 & 24 & 24 & 24 & 24 & 24 \\
\hline Dextrin $^{\mathrm{a}}$ & 14 & 14 & 14 & 14 & 14 & 14 \\
\hline Gelatin $^{\mathrm{a}}$ & 6 & 6 & 6 & 6 & 6 & 6 \\
\hline Egg albumin powder ${ }^{\mathrm{a}}$ & 8 & 8 & 8 & 8 & 8 & 8 \\
\hline Fish meal & 16 & 16 & 16 & 16 & 16 & 16 \\
\hline Cellulose $^{\mathrm{a}}$ & 6.80 & 6.79 & 6.78 & 6.76 & 6.74 & 6.72 \\
\hline Starch soluble ${ }^{a}$ & 10 & 10 & 10 & 10 & 10 & 10 \\
\hline Vitamin $\operatorname{mix}^{\mathrm{b}}$ & 2 & 2 & 2 & 2 & 2 & 2 \\
\hline Mineral $\operatorname{mix}^{\mathrm{c}}$ & 2 & 2 & 2 & 2 & 2 & 2 \\
\hline Soy lecithin ${ }^{\mathrm{d}}$ & 2 & 2 & 2 & 2 & 2 & 2 \\
\hline Fish oil & 7 & 7 & 7 & 7 & 7 & 7 \\
\hline Sod.alginate $^{\mathrm{d}}$ & 2 & 2 & 2 & 2 & 2 & 2 \\
\hline BetaineHCL $^{\mathrm{a}}$ & 0.1 & 0.1 & 0.1 & 0.1 & 0.1 & 0.1 \\
\hline $\begin{array}{l}\text { ButylatedHydroxy Tolu- } \\
\text { ene }(\text { BHT })^{\text {a }}\end{array}$ & 0.1 & 0.1 & 0.1 & 0.1 & 0.1 & 0.1 \\
\hline $\mathrm{ZnSO}_{4} \cdot 7 \mathrm{H}_{2} \mathrm{O}(\mathrm{mg} / \mathrm{Kg})^{\mathrm{e}}$ & 0 & 10 & 20 & 40 & 60 & 80 \\
\hline Total & 100 & 100 & 100 & 100 & 100 & 100 \\
\hline \multicolumn{7}{|c|}{ Proximate composition of diets } \\
\hline Moisture & $8.13 \pm 0.01$ & $8.20 \pm 0.01$ & $8.02 \pm 0.02$ & $8.14 \pm 0.01$ & $8.16 \pm 0.01$ & $8.06 \pm 0.03$ \\
\hline Crude protein $(\mathrm{CP})$ & $40.06 \pm 0.02$ & $41.44 \pm 0.01$ & $41.15 \pm 0.34$ & $40.43 \pm 0.34$ & $40.67 \pm 0.03$ & $41.15 \pm 0.23$ \\
\hline Ether extract (EE) & $10.17 \pm 0.010$ & $10.16 \pm 0.008$ & $11.13 \pm 0.003$ & $10.14 \pm 0.017$ & $10.16 \pm 0.020$ & $11.13 \pm 0.014$ \\
\hline Ash & $3.49 \pm 0.010$ & $2.82 \pm 0.023$ & $3.13 \pm 0.014$ & $3.13 \pm 0.003$ & $2.09 \pm 0.008$ & $3.11 \pm 0.012$ \\
\hline Total carbohydrate & $46.27 \pm 0.040$ & $45.56 \pm 0.202$ & $44.57 \pm 0.348$ & $46.29 \pm 0.326$ & $47.07 \pm 0.049$ & $44.60 \pm 0.242$ \\
\hline Zinc (mg/kg diet) & $16.7 \pm 0.06$ & $28.0 \pm 0.09$ & $42.1 \pm 0.08$ & $59.3 \pm 0.08$ & $72.1 \pm 0.07$ & $92.5 \pm 0.04$ \\
\hline
\end{tabular}


Table 2.The enzyme assays were analysed as per standard method.

\begin{tabular}{lll}
\hline S. N. & Enzymes assayed & References \\
\hline 1. & Lactate dehydrogenase (LDH) & Wroblewski and Ladue (1955). \\
2. & Alanine aminotransferase (ALT) and Aspartate aminotransferase (AST) & Wotton (1964). \\
3. & Superoxide dismutase (SOD) & Misra and Fridovich (1972) \\
4. & Catalase (CAT) & Takahara et al (1960). \\
5. & ATPase & Fiske and Subbarow (1925). \\
6. & Acetylcholine Esterase (AchE) & Augustinsson (1957). \\
7. & Glycogen level & Hassid and Abraham (1957) \\
8. & Protein estimation & Lowry (1951) \\
\hline
\end{tabular}

Table 3. Growth parameters and $\%$ survival of $T$. putitora fry fed with zinc supplemented diets.

\begin{tabular}{llllll}
\hline Treatments & \% Body weight gain & SGR $^{1}$ & FCR $^{2}$ & PER $^{\mathbf{3}}$ & \% survival \\
\hline $\mathbf{T}_{\mathbf{1}}$ & $273.40^{\mathrm{b}} \pm 7.99$ & $2.20^{\mathrm{b}} \pm 0.18$ & $3.36^{\mathrm{e}} \pm 0.25$ & $0.74^{\mathrm{b}} \pm 0.07$ & $98.00^{\mathrm{ab}} \pm 0.58$ \\
$\mathbf{T}_{\mathbf{2}}$ & $306.90^{\mathrm{c}} \pm 16.90$ & $2.34^{\mathrm{c}} \pm 0.22$ & $3.05^{\mathrm{d}} \pm 0.28$ & $0.79^{\mathrm{b}} \pm 0.05$ & $98.33^{\mathrm{b}} \pm 0.33$ \\
$\mathbf{T}_{\mathbf{3}}$ & $315.48^{\mathrm{c}} \pm 15.00$ & $2.37^{\mathrm{d}} \pm 0.16$ & $2.80^{\mathrm{c}} \pm 0.22$ & $0.86^{\mathrm{c}} \pm 0.06$ & $98.67^{\mathrm{b}} \pm 0.89$ \\
$\mathbf{T}_{\mathbf{4}}$ & $354.28^{\mathrm{d}} \pm 18.85$ & $2.52^{\mathrm{e}} \pm 0.23$ & $2.31^{\mathrm{a}} \pm 0.17$ & $1.06^{\mathrm{e}} \pm 0.07$ & $99.33^{\mathrm{b}} \pm 0.67$ \\
$\mathbf{T}_{\mathbf{5}}$ & $345.89^{\mathrm{d}} \pm 21.45$ & $2.49^{\mathrm{de}} \pm 0.19$ & $2.62^{\mathrm{b}} \pm 0.21$ & $0.94^{\mathrm{d}} \pm 0.07$ & $99.33^{\mathrm{b}} \pm 0.33$ \\
$\mathbf{T}_{\mathbf{6}}$ & $237.90^{\mathrm{a}} \pm 14.82$ & $2.02^{\mathrm{a}} \pm 0.14$ & $3.80^{\mathrm{f}} \pm 0.13$ & $0.64^{\mathrm{a}} \pm 0.05$ & $96.41^{\mathrm{a}} \pm 0.34$ \\
\hline
\end{tabular}

Values in the same column with different superscripts ( $a, b, c, d, e$ and f) differ significantly $(p<0.05)$. Data expressed as Mean $\pm \mathrm{SE}, \mathrm{n}=3$ (each replicate had 100 fish); ${ }^{1}$ Specific growth rate; ${ }^{2}$ Feed conversion ratio; ${ }^{3}$ Protein efficiency ratio; $\mathrm{T}_{1}=0 \mathrm{mg} \mathrm{ZN}$; $\mathrm{T}_{2}=10 \mathrm{mg} \mathrm{ZN} ; \mathrm{T}_{3}=20 \mathrm{mg} \mathrm{ZN} ; \mathrm{T}_{4}=40 \mathrm{mg} \mathrm{ZN} ; \mathrm{T}_{5}=60 \mathrm{mg} \mathrm{ZN} ; \mathrm{T}_{6}=80 \mathrm{mg} \mathrm{ZN}$.

in the form of $\mathrm{Zn}$ sulphate $\left(\mathrm{ZnSO}_{4} .7 \mathrm{H}_{2} \mathrm{O}\right)$. Ingredients such as casein, gelatin, cellulose, starch, dextrin, egg albumin powder, fish meal, fish oil, betaine chloride, soy lecithin, vitamin and mineral mixture ( $\mathrm{Zn}$ freemanually prepared and components procured from Himedia Laboratories Ltd., Mumbai, India) were used for diet formulation. The diet composition and proximate analysis are presented in Table 1 . All the ingredients were formulated using the square method of Hardy (1980). The moisture content was determined by drying at $105^{\circ} \mathrm{C}$ to a constant weight. Nitrogen content of the sample was estimated quantitatively by Kjeltec semi-automatic system (Pelican Equipment, Chennai, India) and crude protein was estimated by

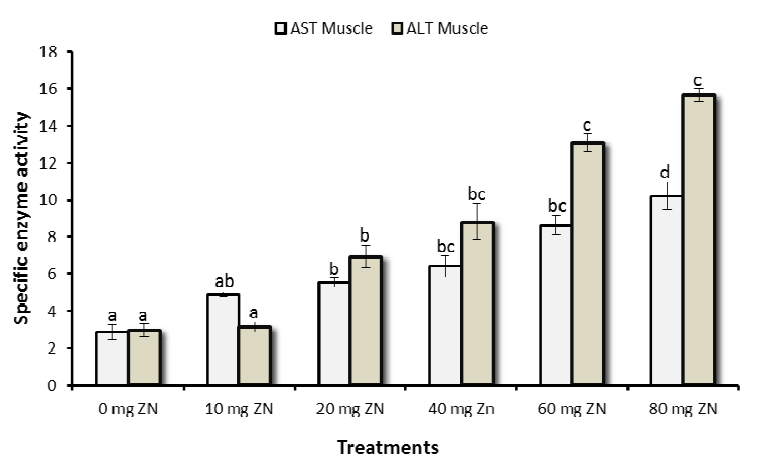

Fig. 2. AST (Aspartate transaminase) and ALT (Alanine transaminase) activity of $T$. putitora fry treated with different concentrations of dietary zinc (values with different superscript differ significantly $(p<0.05)$ and express as mean $\pm S E)(n=6)$. Specific activities of enzymes expressed as AST as nano moles of oxaloacetate released/min/mg protein; ALT as nano moles of sodium pyruvate formed / mg protein/min. multiplying nitrogen percentage by a constant factor 6.25. Ether extract (EE) was measured by solvent extraction method (Socplus SCS-2, Pelican Equipment, Chennai, India) using diethyl ether (boiling point, 40$60{ }^{\circ} \mathrm{C}$ ) as a solvent and ash content was determined by incinerating the samples in a muffle furnace (Macro Scientific Works, Delhi, India) at $600{ }^{\circ} \mathrm{C}$ for $6 \mathrm{hr}$. All the ingredients were analyzed for proximate composition prior to formulation of the test diets employing standard methods (AOAC, 2005).

Growth and survival study: Fish were weighed at the start and every 15 days interval till the termination of the experiment on the 60th day. The growth performances of fry were evaluated in terms of weight gain

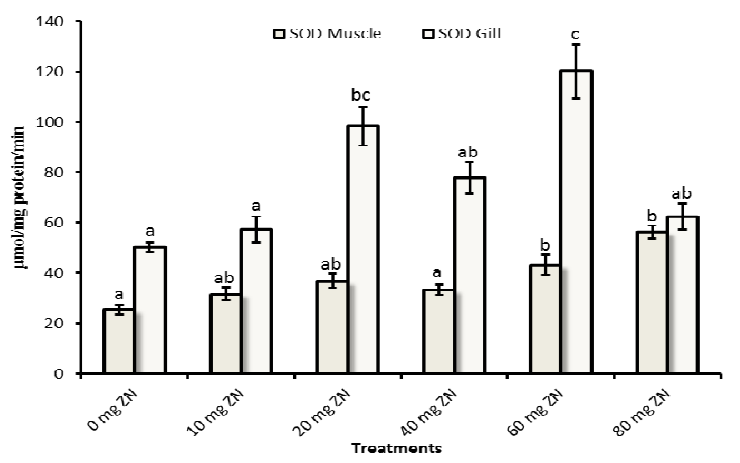

Fig. 3. Superoxide dismutase (SOD) activity in muscle and gill of $T$. putitora fry treated with different concentrations of dietary zinc (values with different superscript differ significantly $(p<0.05)$ and express as mean $\pm S E)$ $(n=6)$.Specific activities of enzymes are expressed as follows: SOD as unit activity (amount of protein required to give $50 \%$ inhibition of epinephrine auto oxidation). 
Table 4. Effect of dietary zinc on ATPase activities in gill and AchE activities in brain of $T$. putitora fry reared for a period of 8 weeks.

\begin{tabular}{lcc}
\hline \multirow{2}{*}{ Treatments } & ${ }^{\mathbf{4}}$ ATPase & ${ }^{\mathbf{5}}$ AchE \\
\cline { 2 - 3 } & Gill & Brain \\
\hline $\mathbf{T}_{\mathbf{1}}$ & $1.88^{\mathrm{ab}} \pm 0.173$ & $0.13^{\mathrm{a}} \pm 0.01$ \\
$\mathbf{T}_{\mathbf{2}}$ & $2.70^{\mathrm{b}} \pm 0.110$ & $0.12^{\mathrm{a}} \pm 0.02$ \\
$\mathbf{T}_{\mathbf{3}}$ & $1.72^{\mathrm{a}} \pm 0.051$ & $0.24^{\mathrm{ab}} \pm 0.01$ \\
$\mathbf{T}_{\mathbf{4}}$ & $1.05^{\mathrm{a}} \pm 0.027$ & $1.30^{\mathrm{b}} \pm 0.09$ \\
$\mathbf{T}_{\mathbf{5}}$ & $2.11^{\mathrm{ab}} \pm 0.176$ & $3.01^{\mathrm{c}} \pm 0.24$ \\
$\mathbf{T}_{\mathbf{6}}$ & $1.37^{\mathrm{ab}} \pm 0.102$ & $3.43^{\mathrm{d}} \pm 0.31$ \\
$\mathbf{P}_{\text {value }}$ & 0.001 & 0.001 \\
\hline
\end{tabular}

Values in the same column with different superscript (a, b, c and d) differ significantly ( $p<0.05$ ). Data expressed as mean $\pm \mathrm{SE}, \mathrm{n}=3$ (each replicate containing pooled samples of 15 fish) $\mathrm{T}_{1}=0 \mathrm{mg} \mathrm{ZN} ; \mathrm{T}_{2}=10 \mathrm{mg} \mathrm{ZN} ; \mathrm{T}_{3}=20 \mathrm{mg} \mathrm{ZN} ; \mathrm{T}_{4}=40$ $\mathrm{mg} \mathrm{ZN} ; \mathrm{T}_{5}=60 \mathrm{mg} \mathrm{ZN} ; \mathrm{T}_{6}=80 \mathrm{mg} \mathrm{ZN} ;{ }^{4}$ Adenosine triphosphatase; ${ }^{5}$ Acetylcholine esterase.

(\%), specific growth rate (SGR), feed conversion ratio (FCR), protein efficiency ratio (PER) and survival (\%). The growth parameters were analyzed employing standard methods of NRC, 2012.

Tissue homogenate preparation: At the end of feeding trial, 15 fish per treatment were sampled. The muscle, intestine, gill and brain of the fishes were dissected out carefully and weighed. It was homogenized with chilled sucrose solution $(0.25 \mathrm{M})$ in a glass tube using tissue homogenizer (Power Gen 500, Fisher Scientific, Germany). A 5\% homogenate was prepared for all the tissues. The tubes were continuously kept in ice bath while homogenizing. The homogenate was centrifuged at $8000 \mathrm{rpm}$ for 15 minutes in a centrifuge (Remi, Mumbai, India). The supernatant was kept frozen at $20^{\circ} \mathrm{C}$ till further analysis.

Enzyme assays : The enzyme assays were analysed as per standard method as mentioned in Table 2.

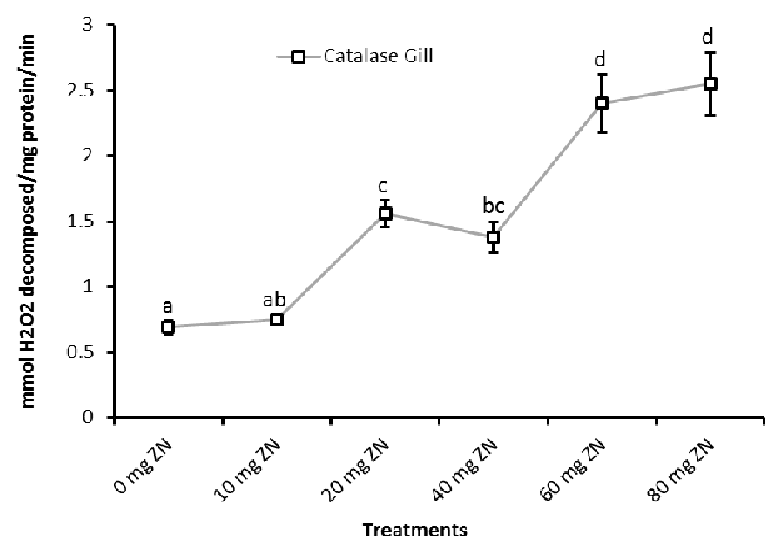

Fig. 4. Effect of dietary zinc on catalase activity in gill of $T$. putitora reared for a period of 8 weeks. Values in the same series with different superscript ( $a, b, c$ and d) signify statistical differences ( $p<0.05$ ), Data expressed as mean $\pm S . E, n=6$ (each replicate containing pooled samples of 15 fish).
Statistical analysis: Data were analyzed by one-way analysis of variance (ANOVA) and the significant difference between the treatments was determined by Duncan's Multiple Range Test (DMRT) using SPSS (Version 16). The level of significance employed was 0.05 .

\section{RESULTS AND DISCUSSION}

Growth and survival study: The growth parameters and \% survival of the experimental animals of different groups at the end of feeding trials are shown in the (Table 3). Supplementation of dietary zinc significantly $(p<0.05)$ affected the weight gain\% and specific growth rate (SGR) of the experimental groups. The highest $(p<0.05)$ weight gain \% and SGR were found in the group fed diet with $40 \mathrm{mg} \mathrm{Zn} \mathrm{kg}{ }^{-1} \operatorname{diet}\left(\mathrm{T}_{4}\right)$. The lowest $(p<0.05)$ value was observed in $\mathrm{T}_{5}$ group fed diet with $80 \mathrm{mg} \mathrm{Zn} \mathrm{kg}^{-1}$ diet. In the present experiment, percentage weight gain and specific growth rate of $T$. putitora fry increased with dietary zinc levels up to a concentration of $40 \mathrm{mg} \mathrm{kg}{ }^{-1}$ dry diet and decreased thereafter. The results indicated that supplemental zinc could improve growth performance of $T$. putitora fry up to a certain extent which is in consistence with the results obtained on Cyprinus carpio (Tan et al., 2011) and Carracius auratus (Hasnat et al., 2012). FCR was recorded a decreasing trend with increase in dietary zinc supplementation up to $40 \mathrm{mg} \mathrm{Zn} \mathrm{kg}^{-1}$ diet and increased thereafter which signify statistical $(p<0.05)$ differences among the zinc treated groups. PER were significantly higher for fish fed the diet supplemented with $40 \mathrm{mg} \mathrm{Zn} \mathrm{kg}^{-1}$ diet $\left(\mathrm{T}_{4}\right)$ than those fed the zinc-un supplemented diet $(p<0.05)$. Lowest \% survival was recorded in the $\mathrm{T}_{6}$ group and highest $\%$ survival was observed in the $\mathrm{T}_{4}$ and $\mathrm{T}_{5}$ groups which did not vary significantly $(p>0.05)$ among other zinc fed groups. The FCR and PER enhanced with increasing dietary zinc levels upto a certain limit. A similar trend was

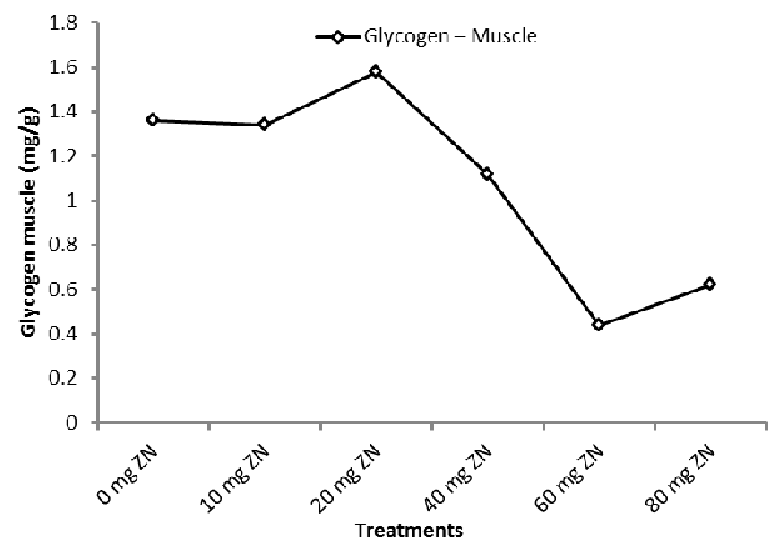

Fig. 5. Effect of dietary zinc on glycogen level in muscle of T. putitora reared for a period of 8 weeks. Data expressed as mean $\pm S . E, n=6$ (each replicate containing pooled samples of 15 fish). 
found in Cyprinus carpio (Tan et al., 2011) and Ctenopharyngodon idella (Liang et al., 2012). These studies suggested that feed intake and weight gain are influenced by levels of dietary zinc.

Enzyme assays: Dietary zinc supplementation significantly $(p<0.05)$ affected lactate dehydrogenase (LDH) activity in muscle of $T$. putitora fry (Fig. 1) in different experimental groups. LDH activity was recorded highest $(p<0.05)$ in $40 \mathrm{mg} \mathrm{ZN}$ group. Lowest value was observed in $80 \mathrm{mg} \mathrm{ZN}$ among all the treatment groups. LDH plays a key role in energy metabolism and acts a pivotal enzyme between glycolytic pathway and Kreb's cycle (Murray et al., 2003). The LDH activity in muscle was observed to be highest in groups supplemented with $40 \mathrm{mg}$ zinc/kg feed. The inhibition of LDH activity was observed in groups deficient in dietary zinc levels. Present results are in accordance with previous findings of Daniela et al. (2012) who affirmed that inhibition of LDH activity may be due to ion imbalance or intracellular action of metal subsequent to initial tissue damage. Effects of dietary zinc on the muscle AST and ALT activity are presented in Fig. 2. Highest $(p<0.05)$ AST activity was observed in $80 \mathrm{mg} \mathrm{ZN}$ group exposed to higher concentration of dietary zinc and lower was observed in control (0 mg ZN) group. An increasing trend was found in AST activity with higher inclusion of dietary zinc which varies significantly among the treatment groups. Similar trend was also noticed for ALT activity in muscle of dietary zinc fed $T$. putitora fry which activity increased concomitantly in highest zinc supplemented group. This increase in activity signifies greater mobilization of amino acids for glucose production via gluconeogenesis to cope up with stress (Chatterjee et al., 2004). Knox and Greengard (1965) also reported that elevated level of transaminase activity would lead to increased feeding of keto acids into TCA cycle thereby affecting oxidative metabolism. However no parallel report is available on the dietary zinc on AST and ALT enzyme activity to substantiate our findings.

Dietary zinc supplementation has significant $(p<0.05)$ influence on SOD activity in gills of treated groups (Fig 3). Highest gill SOD activity was observed in 60 $\mathrm{mg} \mathrm{Zn}$ group fed with $60 \mathrm{mg} \mathrm{Zn} \mathrm{kg}{ }^{-1}$ diet that varied significantly from all other groups. Lowest value was observed in the control group (0 mg ZN) fed without zinc. In the muscle, SOD activity exhibited significant $(p<0.05)$ variation among the treatments. In the muscle the highest and lowest SOD activity was observed in $80 \mathrm{mg} \mathrm{ZN}$ and $40 \mathrm{mg} \mathrm{ZN}$ groups, respectively. The present results showed that the activities of SOD were affected during a 60 days exposure period to dietary zinc. The SOD activity was observed to be low in groups fed with $40 \mathrm{mg} \mathrm{Zn} \mathrm{kg}{ }^{-1}$ diet which showed significant difference in response to control and groups fed with higher concentration of zinc. The results in the present study are in agreement with the findings of (Hasnat et al., 2012), who reported increasing trend of SOD activity in channel catfish and goldfish with increase in dietary zinc intake. These changes indicated a possible mechanism of oxidative stress generated by dietary zinc on $T$. putitora fry. The gill catalase activity was significantly $(p<0.05)$ affected by dietary zinc supplementation (Fig 4). Gill catalase activity was recorded highest in $80 \mathrm{mg} \mathrm{ZN}$ fed groups that varied significantly among all other groups except $60 \mathrm{mg} \mathrm{ZN}$. Many environmental pollutants, including pesticides and heavy metals are capable of inducing oxidative stress in fish (Pandey et al., 2003; Monteiro et al., 2006). The present study reports that the gill catalase activity was significantly higher in group exposed to higher concentration of dietary zinc. However, our findings are not in agreement with the results obtained by Kong et al. (2012) who reported that CAT activity was inhibited in the developing embryos of Carassius auratus under mercury exposure. Therefore the complicated action involved in CAT activity makes it difficult to completely elucidate, which requires further studies on the response mechanism of CAT in the early developmental stage of fish under heavy metal exposure in order to provide additional evidence.

Tissue glycogen: The muscle glycogen level of the experimental groups is presented in Fig. 5. Dietary zinc supplementation has significant $(p<0.05)$ effect on glycogen level in muscle. Highest muscle glycogen level was observed in $20 \mathrm{mg} \mathrm{ZN}$ followed by lowest observed in $60 \mathrm{mg} \mathrm{ZN}$ group. Tissue glycogen is commonly measured parameter of stress response (Manush et al., 2005). Muscle is the chief component on which the nutritive value of fish may be assessed and glycogen is the main components of this tissue. Increase in glucose and concomitant decrease in glycogen on exposure to various environmental toxicants like heavy metals $\mathrm{Zn}, \mathrm{Ni}, \mathrm{Cr}$ and pesticides like sulphoxides, phosphamidon carbonate has been reported by (Sarma et al., 2013) and in muscle tissues of Labeo rohita exposed to pesticides stress (Akhtar et al., 2012). .

In the present study, reduction of gill ATPase activity may be due to alterations in the structure and functions gill plasma membrane or may be due to direct inhibition of zinc on the enzymes. Further research is required to validate these conclusions. Acetylcholine esterase (AchE) is one of the most widely used enzyme biomarker for environmental pollution (Vani et al., 2011). Reduction in AchE enzyme activity indicates an accumulation of acetylcholine in the brain tissue, interfering with energy metabolism of the nervous system, preventing transmission of nervous impulses, and thereby causing behavioral alteration (Sarma et al., 2010). In agreement with the above studies, the present results also evidenced that AchE activity decreased significantly with the increase in dietary zinc concentrations indicating an inhibitory effect of higher dietary 
zinc exposure on AchE activity.

\section{Conclusion}

For propagation of golden mahseer (Tor putitora), proper zinc supplementation in diet for feeding the fishes is very important. To our knowledge this is the first report on studying the effect of optimum dietary zinc supplementation on the early developmental stages of golden mahseer. The present study concluded that dietary supplementations of zinc at the level 40 $\mathrm{mg} \mathrm{Zn} \mathrm{kg}{ }^{-1}$ in diet increased the growth efficiency, enzymatic responses and survival rate of fry of golden mahseer. Enzymatic responses in nutritional studies are useful indices of defining the functional capacities of tissues. The use of enzymatic responses in the present study signifies the physiological responses of $T$. putitora fry, which favours dietary supplementations of zinc at the level $40 \mathrm{mg} \mathrm{Zn} \mathrm{kg-1.} \mathrm{The} \mathrm{results} \mathrm{of} \mathrm{the}$ present study will enable the scientific community to formulate a suitable diet for larval stages of golden mahseer which will be a boon for propagation and conservation of golden mahseer ( $T$. putitora) so as to garner the possibility of establishing the species to commercial aquaculture.

\section{ACKNOWLEDGEMENTS}

The authors are grateful to the Director, Central Institute of Fisheries Education, Mumbai and the Director, Directorate of Coldwater Fisheries Research, Bhimtal for providing facilities for carrying out the experiment. The first author is grateful to Indian Council of Agricultural Research (ICAR), New Delhi, India, for awarding Junior Research Fellowship.

\section{REFERENCES}

AOAC (2005). Official methods of analysis of AOAC, $18^{\text {th }}$ edition, In: Horwitz, W. (Ed.), AOAC, Washington, .D.C., 1094.

Augustinsson, K.B.(1957). The reaction of acetylcholine esters and other carboxylic acid derivatives with hydroxylamine and its analytical application. J.Biol.Chem., 180: 249-261.

Akhtar, M.S., Pal, A.K., Sahu, N.P., Alexander, C. and Gupta, S.K. (2012). Effects of dietary pyridoxine on growth and biochemical responses of Labeo rohita fingerlings exposed to endosulfan. Pest. Biochem. Physiol., 103: 23-30

Akhtar, M.S., Sarma, D. and Pandey, N.N. (2013). Activities of digestive enzymes during ontogenic development of golden mahseer (Tor putitora) larvae. Indian J. Ani. Sci., 83 (5): 100-103.

Chatterjee, N., Pal, A.K., Manush, S.M., Das, T. and Mukherjee, S.C. (2004). Thermal tolerance and oxygen consumption of Labeo rohita and Cyprinus carpio early fingerlings acclimated to three different temperatures. Journal of Thermal Biology. 29: 265-270

Daniela, T., Munteanu, M.C., Andeea, C. S. and Anca, D. (2012). Changes in lactate dehydrogenase activity in Carassius auratus gibelio (L. Pysces) kidney, gills and intestine induced by acute exposure to copper. Romanian Biotechnological Letters. 17 (6): 7873-7880

Fiske, C.H. and Subbarow, Y. (1925). The colorimetric determination of phosphorous. J. Biol. Chem., 66: 375-400

Hasnat, A., Babitha, Rani., Kohli, M.P.S. and Chandraprakash, G. (2012). Assessment of zinc status and its effect on thermal stress resistance in Carassius auratusfry. Israeli J. Aquacult. - Bamidgeh., 64: pp. 13

Hardy, R. (1980). Fish feed formulation, In: ADCP (Eds.), Fish feed Technology, Agriculture development coordination programme. FAO/ADCP/Rep., 80(1-1): 233-239.

Hassid, W. and Abraham, S. (1957.) Chemical procedures for analysis of polysaccharides. In: Colowick, SP, Kaplan, NO (eds.) Methods in Enzymology, Academic Press, New York, pp34-37

Kong, X., Wang, S., Jiang, H., Nie, G. and Li, X. (2012). Responses of acid/alkaline phosphatase, lysozyme, and catalase activities and lipid peroxidation to mercury exposure during embryonic development of goldfish Carassius auratus. Aquatic Toxicology. (120-121): 119125

Lall, S. P. (2002). The minerals. In: Fish Nutrition. Halver, J. E., Hardy, R.W. (eds.) 3rd ed. Academic Press, San Diego, CA, pp $259-308$

Liang, J.J., Yang, H.J., Liu, Y.J., Tian, L.X. and Liang, G.Y. (2012). Dietary zinc requirement of juvenile grass carp (Ctenopharyngodon idella) based on growth and mineralization. Aquaculture Nutrition. 18: 380-387.

Lowry, O. H, Ronebrough, N. J, Farr, A. L and Randell, R. J. (1951). Protein measurement with Folin phenol reagent. J. Biol. Chem., 193: 265-276

Manush, S.M., Pal, A.K., Das, T. and Mukherjee, S.C. (2005). Dietary high protein and vitamin C influence in mitigating stress due to chelate claw ablation in Macrobrachium rosenbergii males. Comp. Biochem. Physiol.A. $142: 10-18$

Misra, H. P. and Fridovich, I. (1972). The role of superoxide anion in the auto oxidation of epinephrine and a simple assay superoxide dismutase. J. Biol. Chem., 247(10): 3170-3175

Monteiro, D.A., Almeida, J.A., Rantin, F.T. and Kalinin, A.L. (2006). Oxidative stress biomarkers in the freshwater characid fish, Bryconcephalus, exposed to organophosphorus insecticide Folisuper 600 (methyl parathion). Comp. Biochem. Physio., 143C:141-149

Murray, H.M., Gallant, J.W., Perez-Casanova, S.C., Johnson and Douglas, S.E. (2003). Ontogeny of lipase expression in winter flounder. J. Fish Biol., 62: 816-833.

Knox, W.E. and Greengard, O. (1965). In: An introduction to enzyme physiology, Advan. Enzyme Regul. (ed. Weber, G.). Pergamon Press, New york, London, 3: 247-248.

Pandey, S., Parvez, S., Sayeed, I., Haque, R., Bin-Hafeez, B. and Raisuddin, S. (2003). Biomarkers of oxidative stress: a comparative study of river Yamuna fish Wallago attu. Sc. Total Environ., 309: 105-111

Sarma, D., Haldar, R.S., Das. P. and Mahanta, P.C. (2010). Management in seed production of golden mahseer, Tor putitora in hatchery conditions. Aquacult. Asia. 15 (4): 31-35

Sarma, K., Prabakaran, K., Krishnan, P., Grinson, G. and Kumar, A. (2013). Response of a freshwater airbreathing fish, Clarias batrachus to salinity stress: an experimental case for their farming in brackish water 
aquaculture areas in Andaman, India. Aquacult. Intr., 21: $183-196$

Takahara, S., Hamilton, B.H., Nell, J.V., Kobra, T.Y., Ogura, Y. and Nishimura, E.T. (1960). Hypocatalesemia, a new generis carrier state. Journal of Clinical Investigation. 29:610-619

Tan, L. N., Feng, L., Liu, Y., Jiang, J., Jiang, W.D., Hu, K., Li, S.H. and Zhou, X.Q. (2011). Growth, body composition and intestinal enzyme activities of juvenile Jian carp (Cyprinus carpio var. Jian) fed graded levels of dietary zinc. Aquaculture Nutrition. 15: 338-345

Vani, T., Saharan, N., Mukherjee, S.C., Ranjan, R., Kumar, R. and Brahmchari, R.K. (2011). Deltamethrin induced alterations of hematological and biochemical parameters in fingerlings of Catla catla (Hamilton.) and their amelioration by dietary supplement of vitamin C. Pest. Biochem. Physiol. 101: 16-20.

Wotton, I.D.P. (1964). Microanalysis. In: Medical Biochemistry. Churchill J, Churchill, A (eds.) $4^{\text {th }}$ edn. London, pp101-107.

Wroblewski, L. and Ladue, I. (1955). LDH activity in blood. Proc. Soc. Exp. Biol. Med., 90: 210-213.

Yousef, M.I., Hendy, H.A., Demerdash., F.M. and Elagamy, E.I. (2002). Dietary zinc deficiency induced-changes in the activity of enzymes and the levels of free radicals, lipids and protein electrophoretic behavior in growing rats. Toxicology, 175(1-3): 223-233. 